\title{
Effectiveness and Contributions Analysis of PT. Bank Papua Owned Enterprises (BUMD) toward Regional Income (PAD) in Papua Province
}

\author{
Elsyan Rienette Marlissa., SE.,M.Si \\ Cenderawasih University Papua, Indonesia \\ elsyan_marlissa@yahoo.com
}

\begin{abstract}
Government of Papua Province by placing the regional enterprises as the one of the assets that will be used to provide a real contribution to the local economy, many steps and efforts put enterprises as an institution that has a chance to be an advance contributor to contribute to the economy and income for the region through the placement funds by the government in business institutions established under Regional Regulation. The placement of these funds will take a role in stimulating economic growth, which may create additional value, employment, and foreign exchange. This research is purposed to determine the effectiveness of the financial capacity of the PT.Bank Papua Owned Enterprises (Ind: BUMD) toward the income target of PT.Bank Papua profit and find out how much the contribution of the Regional Owned Enterprises (Ind: BUMD) on PT.Bank Papua income of Papua Province. The method used is the analysis of the effectiveness and contribution analysis. The results shows that PT.Bank Papua profit is very effective based on the financial balance sheets and PT.Bank Papua income (loss), PT. Bank Papua Deposits have very effective category, PT.Bank Papua postal giro has effective category. PT. Bank Papua financial ratio analysis, liquidation analysis or LDR PT.Bank Papua has a category of highly effective, the analysis of acceptance or BOPO PT.Bank Papua has effective category. Bank of Papua contribution to regional income of Papua Province was the highest in 2010, reaching Rp.23.339.102.363 or 6.00\%. Suggestion findings show that Bank of Papua in the growth and development of enterprises needs to be fostered and implemented, especially on the motivation to improve the regional company's operating profit reception for regional income. The efforts can be done through increasing the expertise and the professionalism of its staff and their directors in running the company as a purely commercial business that promotes/prioritize the efficiency considerations. PT.Bank Papua Directors and staff (enterprises) in achieving the profit should be continued to improve the development of the soul and spirit of entrepreneurship.
\end{abstract}

Keywords: Effectiveness of Financial Capability, Contributions, Papua

\section{Introduction}

Enterprises ideally (BUMD) is one source income of local government. BUMD is a manifestation of the role of local government in local economic development. In the effort to carry out the principal functions and duties for the population in Papua province, Papua provincial government set up several regional-owned enterprises (BUMD) with the aims to provide services to the public, but on the other hand Regional Owned Enterprises (BUMD) is also expected to contribute to regional income. Papua Provincial Government's expectations by placing the regional enterprises as the one of the assets that will be used to provide a real contribution to the local economy, many steps and efforts put enterprises as an institution that has a chance to be an advance contributor to contribute to the economy and income for the region through the placement funds by the government in business institutions established under Regional Regulation. The placement of these funds will take a role in stimulating economic growth, which may create additional value, employment, and foreign exchange. However, in its development, enterprises became one of the region's financial problems. Not only failed to become a source of income, enterprises could burden the local finances. Research conducted by Setyawan and Riyardi, providing interesting findings related to the performance of enterprises. Enterprises in several cities in Central Java was not efficient in their operational. Their contributions to the regional government budget are not comparable with the assets owned. The average contribution of enterprises in Indonesia toward regional income is less than 1\% (percent). 
Papua provincial government has the enterprises, they are Bank of Papua enterprises engaged in finance and banking are expected to contribute to an increase in the income as well as the regional economy. Bank of Papua is the largest contributor in 2012 which amounted Rp.13.258.603.425,00 or decreased by Rp.10.080.498.938,00 and Development Fund of Development Bank of Rp.6.629.301.712,00 or decreased by Rp.372.428.997,00 compared in 2011. In its development, the enterprises of Papua Provincial government has not been able to increase the role and functions as the main locomotive as a major contributor in the formation PAD Papua Province. Another problem that is not inability of local governments to manage enterprises professionally as a private company, and yet at the same potential and the identification of sources of local revenue. The problems that exist for this is information related to the performance of the Regional Owned Enterprises (BUMD) in Papua province is still very limited, therefore it is necessary to conduct the performance evaluation of regional-owned enterprises (enterprises) in Papua Province as a whole both financial performance and non-financial performance in providing services to the public (social function).

Performance is one of the important factors that demonstrate the effectiveness and efficiency of an organization in order to achieve its objectives. Performance of Regional Owned Enterprises (BUMD) is important to analyze because it is used as a material consideration in decision making in all management aspects. If enterprises have poor performance, then it must be addressed immediately to prevent enterprises from bankruptcy. This is certainly to be anticipated in a way to study the effectiveness of public enterprises to the economic empowerment of Papua and increase the contribution of regional income in Papua Province. Based on this background, the author would like to know how is the effectiveness of the Financial Capability of PT.Bank Papua Owned Enterprises (BUMD) toward the income target of PT.Bank Papua profit. How big Contributions of Regional Owned Enterprises (enterprises) to the PT.Bank Papua income of Papua Province.

\section{Literature Review}

The description of effectiveness according to Hidayat (1986) is explained below: "Effectiveness is a measure that states how far the target (quantity, quality and timing) that has been reached. The greater the percentage of targets achieved, the higher its effectiveness ". And the effectiveness according to Budi Prasetyo Saksono (1984): "Effectiveness is the extent of attachment of output achieved with expected output of a number of inputs". Notions of effectiveness can be concluded that the effectiveness is a measure that states how far the target (quantity, quality and timing) that has been achieved by the management, in which the target has been determined in advance. According Mardiasono (2002: 132), the original income constitutes acceptance area tax sector, retribution, the results of which are separated wealth management area, the results of companies belonging to the region, and other legitimate income. According Setyawan and Riyardi (2000), the performance of enterprises in several cities in Central Java was not efficient in their operation. Their contributions to the budget are not comparable with the assets owned. The average contribution of enterprises in Indonesia toward regional income is less than $1 \%$ (percent).

\section{Methodology}

The study was conducted in PT.Bank Papua of Jayapura representing Papua Province. The type of data used are primary data. The data collected through direct survey of the respondents (the chairman and directors of PT.Bank Papua) Secondary data is historical data or documents gathered or obtained primarily from the PT.Bank Papua which is related and considered relevant. The data analysis method uses the analysis of the effectiveness and contribution. Measuring the performance evaluation of enterprises to regional income of Papua Province.This research uses several analytical tools as follows in order to determine the relationship effectiveness between actual incomes derived from income profit component of enterprises toward the income target of profit enterprises:

Profit realization of enterprises (BUMD)

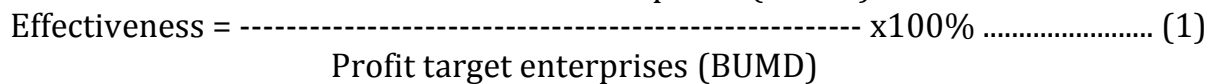


If the results of the effectiveness calculation of the instrument profit enterprises generate numbers/percentages close to $100 \%$, the profit of enterprises is more effective instrument, and to see its effectiveness by comparing the effectiveness of the years concerned with the effectiveness of the previous year. Department of Home Affairs with Ministry of Home Affairs No.690.900-327, 1996 categorize the ability of financial autonomous region effectiveness into 5 levels of effectiveness as shown in the following Table 1:

Table 1: Financial effectiveness of Autonomous Region

\begin{tabular}{ll}
\hline Effectiveness of Financial Capability & Independence Ratio (\%) \\
\hline Very Effective & $>100$ \\
Effective & $>90-100$ \\
Quite Effective & $>80-90$ \\
Less effective & $>60-80$ \\
Ineffective & $\leq 60$ \\
\hline
\end{tabular}

Source: Department of Home Affairs, 1996

The contributions that can be donated from the profit of Regional Owned Enterprises to regional income.

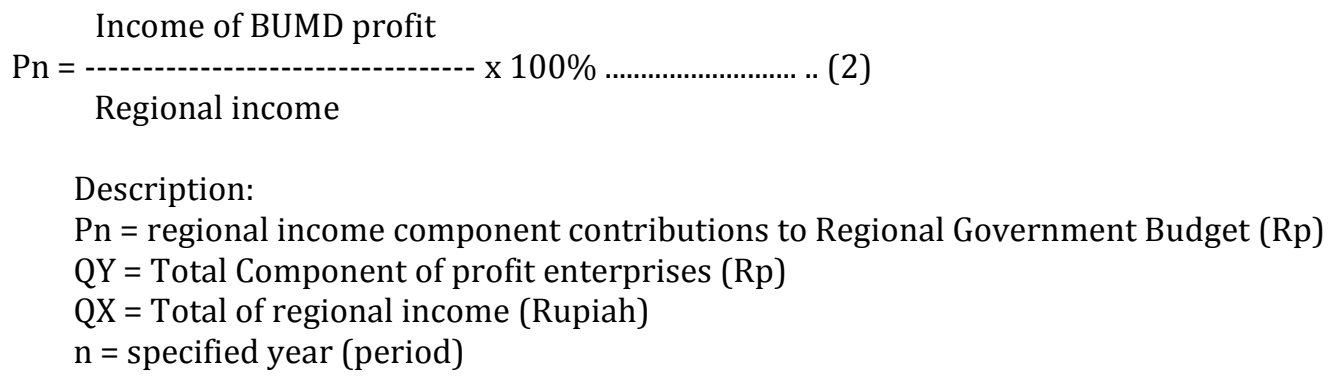

\section{Finding and Discussion}

Financial report of PT.Bank Papua in 2013 can be used as a reference of how the use and funds management which is spent during the last three years to assess the achievement of financial performance achievement in PT.Bank Papua, which will then be used as a rationale for the planning and determining the policy strategy in decision making for the interested parties. Here we will show the results of the financial statements made by PT.Bank Papua.

Table 2: Financial Report of PT.Bank Papua in 2013

\begin{tabular}{|c|c|c|c|}
\hline DESCRIPTION & $\begin{array}{l}\text { 31-Dec-13 } \\
\text { Quart-IV 'in } 2013 \\
\end{array}$ & $\begin{array}{l}\text { 31-Dec-12 } \\
\text { Quart-IV '2012 }\end{array}$ & $\begin{array}{l}\text { 31-Dec-11 } \\
\text { Quart-IV '2011 }\end{array}$ \\
\hline ASSET & $17,805,185$ & $14,865,514$ & $13,707,654$ \\
\hline CREDIT & $11,378,388$ & $8,198,759$ & $5,220,031$ \\
\hline TOTAL DPK & $13,468,916$ & $11,443,267$ & $10,895,253$ \\
\hline $\begin{array}{l}\text { TOTAL DPK (Beyond the Local } \\
\text { Government Fund) }\end{array}$ & $9,275,200$ & $8,023,764$ & $6,841,843$ \\
\hline GIRO & $6,951,249$ & $6,131,956$ & $6,498,021$ \\
\hline GOVERNMENT GIRO & $4,193,716$ & $3,419,503$ & $4,053,410$ \\
\hline SAVINGS & $4,621,902$ & $4,331,911$ & $3,634,745$ \\
\hline DEPOSIT & $1,895,766$ & 979.401 & 762.487 \\
\hline TOTAL INCOME & $2,380,692$ & $2,034,205$ & $1,917,035$ \\
\hline TOTAL COST & $1,812,371$ & $1,606,349$ & $1,522,343$ \\
\hline PROFIT AND LOSS & 568.321 & 427.856 & 394.692 \\
\hline \multicolumn{4}{|l|}{ FINANCIAL RATIOS } \\
\hline ROA & $3: 19 \%$ & $2.88 \%$ & $2.88 \%$ \\
\hline BOPO & $68.10 \%$ & $70.80 \%$ & $69.18 \%$ \\
\hline
\end{tabular}




\begin{tabular}{llll} 
NPL Gross & $1: 14 \%$ & $0.69 \%$ & $0.71 \%$ \\
LDR & $84.78 \%$ & $71.76 \%$ & $48.01 \%$ \\
\hline
\end{tabular}

Effectiveness Analysis: Based on the results of the effectiveness calculation of the of the instrument profit PT.Bank Papua generate numbers/percentage of the average per year is greater than $100 \%$, it shows the instrument profit PT.Bank Papua very effective, and to look at its effectiveness by comparing the effectiveness of the years concerned with the effectiveness of the previous year.

Table 3: Effectiveness of Financial PT.Bank Papua

\begin{tabular}{llllll}
\hline \multirow{2}{*}{ DESCRIPTION } & \multicolumn{2}{l}{ Effectiveness } & \multicolumn{3}{l}{ Financial Capabilities } \\
& $\mathbf{2 0 1 3 - 2 0 1 4}$ & $\mathbf{2 0 1 2 - 2 0 1 3}$ & $\mathbf{2 0 1 1 - 2 0 1 2}$ & Average & \\
\hline ASSET & $93.90 \%$ & $119.78 \%$ & $108.45 \%$ & 107372 & Very Effective \\
CREDIT & $103.44 \%$ & $138.78 \%$ & $157.06 \%$ & 133095 & Very Effective \\
TOTAL DPK & $85.96 \%$ & $117.70 \%$ & $105.03 \%$ & 102897 & Very Effective \\
$\quad$ GIRO & $66.62 \%$ & $113.36 \%$ & $94.37 \%$ & 91451 & Effective \\
SAVINGS & $119.72 \%$ & $106.69 \%$ & $119.18 \%$ & 115199 & Very Effective \\
$\quad$ DEPOSIT & $137.91 \%$ & $193.56 \%$ & $128.45 \%$ & 153307 & Very Effective \\
TOTAL INCOME & $105.80 \%$ & $117.03 \%$ & $106.11 \%$ & 109647 & Very Effective \\
TOTAL COST & $101.41 \%$ & $112.83 \%$ & $105.52 \%$ & 106930 & Very Effective \\
PROFIT AND LOSS & $122.72 \%$ & $132.83 \%$ & $108.40 \%$ & 121318 & Very Effective \\
$\quad$ FINANCIAL RATIOS & & & & & \\
ROA & $115.09 \%$ & $110.90 \%$ & $99.96 \%$ & 108649 & Very Effective \\
BOPO & $93.82 \%$ & $96.18 \%$ & $102.34 \%$ & 97449 & Effective \\
NPL GroSS & $49.58 \%$ & $164.89 \%$ & $97.82 \%$ & 104096 & Very Effective \\
LDR & $120.68 \%$ & $118.14 \%$ & $149.46 \%$ & 129426 & Very Effective \\
\hline
\end{tabular}

The financial report of the balance sheet and profit (loss) of PT.Bank Papua, PT.Bank Papua Post Deposits have the highest level of effectiveness in the amount of 153 307, with the category of very effective, PT.Bank Papua postal giro has the lowest level of effectiveness that is equal to 91451 with an effective category. A financial ratio analisys of PT.Bank Papua, PT.Bank Papua LDR analysis of liquidation or have the highest level of effectiveness in the amount of 129 426, with a category of highly effective, the analysis of income or BOPO PT.Bank Papua has the lowest level of effectiveness that is equal to 97449 with an effective category.

Analysis of Bank of Papua Contributions towards Regional Income of Papua Province: Contribution analysis is an analysis instrument that is used to determine the contribution profit that can be donated from Regional Owned Enterprises (BUMD) to the income of PT.Bank Papua. PT.Bank Papua carry out their duties and functions as a financial institution that guarantees the stability of money circulation and local economic development in Papua, Bank of Papua is also the enterprises that must be able to contribute to regional Government income of Papua Province. In 2013 and 2012 the contribution of Bank of Papua is very effective because it fits with the target. While the Bank of Papua in 2011 contributed to the PAD less effective.

Table 4: Target development and realization of Bank of Papua Contributions toward Regional Income of Papua Province

\begin{tabular}{lllll}
\hline YEAR & TARGET & REALIZATION & $\begin{array}{l}\text { PERCENT } \\
\text { (\%) }\end{array}$ & CATEGORY \\
\hline 2013 & 17.704962 billion & $17,704,962,366$ & 100.00 & Very Effective \\
2012 & $15,819,247,890$ & $15,819,247,890$ & 100.00 & Very Effective \\
2011 & $24,339,102,363$ & $13,528,603,425$ & 55.58 & Less Effective \\
2010 & $23,340,282,764$ & $23,339,102,363$ & 99.99 & Very Effective \\
2009 & $23,340,282,764$ & $22,251,246,013$ & 95.33 & Very Effective \\
AVERAGE & $20,908,775,556$ & $18,528,632,411$ & 90.18 & Very Effective \\
\hline
\end{tabular}


PT.Bank Papua contribution to regional income of Papua province was the highest in 2010, reaching Rp.23.339.102.363, or $6.00 \%$, but the percentage is still low compared to the year of 2009. After that continued to fall until it reaches Rp.17.704.962.366 or $2.79 \%$ in 2013.

Table 5: PT.Bank Papua contributions toward regional income Papua Province in 2009 to 2013

\begin{tabular}{llll}
\hline Year & Regional Income & Bank of Papua Contribution & Percent \% \\
\hline 2013 & 633726316291 & $17,704,962,366$ & 2,79 \\
2012 & 591927500335 & $15,819,247,890$ & 2.67 \\
2011 & 363100749954 & $13,528,603,425$ & 3.73 \\
2010 & 388840404256 & $23,339,102,363$ & 6.00 \\
2009 & 369727113036 & $22,251,246,013$ & 6.02 \\
\hline
\end{tabular}

It clearly shows that the contribution of PT.Bank Papua income of Papua Province continued to decline both in the percentage and rupiah. These findings coincide with research conducted by Setyawan and Riyardi, providing interesting findings related to the performance of enterprises. Enterprises in several cities in Central Java was not efficient in their operation. Their contributions to the regional budget are not comparable with the assets owned. The average contribution of enterprises in Indonesia toward the regional income less than $1 \%$ (percent).

\section{Conclusion}

PT.Bank Papua is very effective based on PT.Bank Papua financial balance sheets and profit (loss), PT.Bank Papua Post Deposits have the highest level of effectiveness in the amount of 153.307, with the category of very effective, PT.Bank Papua Postal giro has the lowest level of effectiveness that is equal to 91451 with an effective category. For PT.Bank Papua financial ratio analysis, liquidation analysis or LDR PT.Bank Papua has the highest level of effectiveness in the amount of 129.426, with the category of highly effective, the analysis of acceptance or BOPO PT.Bank Papua has the lowest level of effectiveness that is equal to 97.449 with an effective category. Bank of Papua contribution towards to the regional income in 2009, 2011, 2012 and 2013 was very effective, except in 2010 was less effective. Bank of Papua contribution to regional income of Papua Province was highest in 2010, reaching Rp.23.339.102.363, or $6.00 \%$.

\section{References}

Bank Papua. (2015). The Profile of the Bank Papua. Website PT. Bank Papua in 2015.

Bank Papua. (2015). Annual Report PT. Bank Papua in 2014.

Budi Prasetyo Saksono (1984). The teory of the effectiveness. Publisher PT. Graha Gresik. Jakarta.

Hidayat. (1986). The effectiveness teory of the performance of the Labours. Publisher Gajah Mada University Press. Yogyakarta.

Mardiasono. (2002). The autonomy and the financial management of the local government. Publisher Andi, Yogyakarta.

The regulation of the ministry of Home Affairs, Number 13 of 2006, The Republic Indonesia regarding the the financial management of the Local Government.

Setyawan Anton A. \& Riyardi A. (2000). The development of the intellectual capital in the BUMD. District Sukoharjo, Journal Research Science Social, University Muhammadiyah Surakarta.

The Law on Indonesian, Number, 5 of 1962, regarding to The Local Companies. 